\title{
Study of Integrate Methods Chemical and Cultural Control of Weeds to Wheat (Triticum aestivum L.)
}

\author{
Zoheir.Y.Ashrafi (Corresponding author) \\ Department of Weed Science, Faculty of Agronomy and Animal Science \\ University College of Agricultural and Natural Resource \\ University of Tehran and Teacher at Payame Noor University (PNU), Tehran State, Iran \\ Tel: 98-261-280-1011_E-mail: z.y.ashrafi@gmail.com \\ Sedigheh sadeghi \\ Department of Weed Science, Faculty of Agronomy and Animal Science \\ University College of Agricultural and Natural Resource \\ University of Tehran and Teacher at Payame Noor University, Tehran State, Iran \\ Tel: 98-912-528-8240 E-mail:sadeghi58@gmail.com \\ Hamid.R.Mashhadi \\ Department of Weed Science, Faculty of Agronomy and Animal Science \\ University College of Agricultural and Natural Resource, University of Tehran, Iran \\ E-mail: h.rahimian.m@ut.ac.ir
}

The research is financed by University of Tehran (Sponsoring information)

\begin{abstract}
Aabstract
An experiment was laid out to study the effect of different weed management practices and row spacings on the yield and yield components of wheat variety Karaj-2 during 2005 - 2006 at Agronomy Research Farm, University College of Agricultural and Natural Resource, University of Tehran. Wheat was sown at row spacing of 20, 30 and $40 \mathrm{~cm}$, while herbicides applied were broad spectrum 2,4-D butyl Ester: 72 EC + Isoproturon 75 WP @ 865 ml and 865 g ha-1 respectively, broad leaf Buctril M 40 EC@1.25 liter ha-1 and a weedy check (no herbicide). Row spacing significantly affected all parameters. Minimum weeds density m-2 and maximum spikelets spike-1, grain yield, harvest index and net income were found in $20 \mathrm{~cm}$ row spacing. While number of grains spike- 1 were highest in $30 \mathrm{~cm}$ row spacing. Among herbicides, minimum weeds density $\mathrm{m}^{-2}$ and maximum spikelets spike ${ }^{-1}$, grains spike ${ }^{-1}$, grain yield, harvest index and net income were found in plots treated with broad-spectrum herbicide followed by Buctril-M 40 and the weedy check, respectively. It is concluded that maximum grain yield and net income can be obtained using broad spectrum (grasses + broad leaved) herbicides and narrow row spacing.
\end{abstract}

Keywords: Integrate methods, Herbicides, Row spacing, Wheat, Triticum aestivum, Yield

\section{Introdution}

Wheat (Triticum aestivum L.) is globally important cereal crop with respect to area and production. In Pakistan, it ranks first among the cereal crops and occupies about $66 \%$ of the annual food crop area (Anonymous, 2003). The area in Iran under wheat cultivation in 2005-2006 was 8.14 million hectares, producing 18.54 million tons with an average yield of $2.28 \mathrm{t} \mathrm{ha}^{-1}$ (Anonymous, 2005). The wheat yield in Iran is lower as compared to other advanced countries of the world. Cultural management plays significant role in increasing production ha ${ }^{-1}$. Among which weed control, row spacing and quality seed can improve yield by about 50 - 70 percent (Ashrafi et al, 2009, Burns, 1944). Adapting the above-mentioned technology in the country we will be able to export more wheat to other countries or to allocate some area of wheat to the production of other exportable agricultural commodities. Weeds are one of the major constraints in 
crop production. They compete with crop plants for light, moisture, nutrients and space. Weeds also increase harvesting costs, require costly cleaning of seeds, clog water ways, and increase fire hazards (Arnon, 1972; Ashrafi et al, 2009; Rahnavard et al, 2009). Young et al., (1994) reported that weeds reduced the wheat yield from 9.50 to $16.03 \%$ depending on the intensity of weeds. It is therefore, essential to control weeds in order to obtain maximum yield of wheat having good quality grains. Management of weeds has been practiced from time immemorial by manual labor or animal drawn implements. These methods, besides being laborious and tiresome are expensive due to the increase in labor, animal and implements cost (Iqbal, 1994) and as such have stimulated interest in the use of chemical weeds control. But, the exclusive reliance on herbicides has resulted in pollution of the environment and inter- and intra-specific shifts (Integrating the chemical with cultural is an excellent option for the weed control (Hassan and Marwat, 2001). Proper row spacing is another most important management factor affecting the agronomic characteristics of wheat and weed infestation (Marwat et al, 2002). Narrow row spacing produces high leaf area index, which results in more interception of photo-synthetically active radiation and dry matter accumulation (Ashrafi et al, 2009Tollenaar and Aguilera, 1992 and Dwyer et al., 1991).

A limited research has been carried out in Iran on the integrated efforts of wheat production. In order to ascertain the integrated use of crop management practices, the present study was conducted in irrigated plains of Karaj City with the objectives to evaluate the impact of integrated weed management viz. chemical and cultural on the agronomic parameters and economics of wheat production.

\section{Materials and methods}

A study was undertaken on wheat variety Karaj-2 at the Research Farm, Agronomy Research Farm, University College of Agricultural and Natural Resource, University of Tehran during the winter season 2005 - 2006. The experiment was laid out in factorial arrangement in randomized complete block design (RCBD) with three replications. The factors included in the experiment were: row spacing $(20,30,40 \mathrm{~cm})$ and herbicides including broad-spectrum (2,4-D Butyl Ester $72 \mathrm{EC}+$ Isoprotouron $75 \mathrm{WP} @ 865 \mathrm{ml} \mathrm{ha}^{-1}$ and $865 \mathrm{~g} \mathrm{ha}^{-1}$, respectively), broad leaf herbicide (Buctril M 40 EC (a) $1.25 \mathrm{l} \mathrm{ha}^{-1}$ ) and a weedy check. The standard seed rate of $120 \mathrm{~kg} \mathrm{ha}^{-1}$ was used. A standard dose of 120:70 N:P kg $\mathrm{ha}^{-1}$ was used in the form of urea and di-ammonium phosphate. Half the nitrogen and full dose of phosphorus was applied at the time of seedbed preparation, while remaining half of the nitrogen was applied at first and second irrigation. The herbicides were sprayed 40 days after sowing to control all germinated weeds. Data on individual observations were recorded using the following procedure: weed density for grasses and broad leaf weeds was determined 15 days after herbicides application. A quadrate of one $\mathrm{m}^{2}$ made of iron wire was placed randomly in three places in each sub-plot and weeds were counted and then mean was calculated $\mathrm{m}^{-2}$. Fertile spikelets spike ${ }^{-1}$ was counted at the time of harvest from ten randomly selected spikes from each treatment and the mean spikelets spike ${ }^{-1}$ were calculated. The grains spike ${ }^{-1}$ were counted by threshing the above spikes, counting the grains and subsequently computing the mean grains spike $\mathrm{e}^{-1}$. The grain yield $\left(\mathrm{t} \mathrm{ha}^{-1}\right)$ was recorded by obtaining per plot yield in $\mathrm{kg}$ and subsequently converting the data into $\mathrm{tha}^{-1}$. The data on harvest Index (H.I) were obtained by using the following formula:

$$
\text { H.I. }=\frac{\left(\text { Economic yield }\left(\mathrm{t} \mathrm{ha}^{-1}\right) \times 100\right.}{\left(\text { Biological yield }\left(\mathrm{t} \mathrm{ha}^{-1}\right)\right.}
$$

Economics of crop production: Cost of all operations/inputs included in the production of wheat crop was calculated $\mathrm{ha}^{-1}$ (i.e. manual labour, machine labour, animal labour, land rent, seed, fertilizers, herbicides, water rates etc.). Gross income for main product (grain) and by product (straw) was calculated. The net income (Profit ha ${ }^{-1}$ ) was calculated by subtracting production cost from the gross income.

Analysis of variance and mean separation tests were applied according to the method described by Gomez and Gomez (1984) using the MSTAT-C computer software package.

\section{Results and Discussion}

\subsection{Grasses weeds density $\left(m^{-2}\right)$}

The effect of herbicides, row spacing and interaction of herbicide with row spacing on grasses weeds density $\mathrm{m}^{-2}$ was

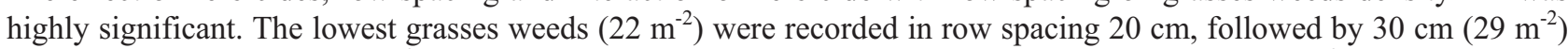
and $40 \mathrm{~cm}$ row spacing $\left(34 \mathrm{~m}^{-2}\right)$ (Table 1$)$. Among herbicides minimum number of grasses weeds $\mathrm{m}^{-2}$ were recorded in treatments treated with broad-spectrum herbicide $\left(12 \mathrm{~m}^{-2}\right)$ followed by broad leaved $\left(35 \mathrm{~m}^{-2}\right)$ and weedy check $\left(38 \mathrm{~m}^{-2}\right)$ [Table 1]. In the interaction of row spacing with herbicides, minimum grasses weeds $\left(8 \mathrm{~m}^{-2}\right)$ were recorded in row spacing $20 \mathrm{~cm}$ with broad spectrum herbicide treated plots, while maximum $\left(43 \mathrm{~m}^{-2}\right)$ were found in row spacing $40 \mathrm{~cm}$ with control treatment (Table 1). The lowest density $\mathrm{m}^{-2}$ of grasses weeds recorded in $20 \mathrm{~cm}$ row spacing might be due to more competition of wheat crop for development resources as compared to wider row spacing. These results were in agreement with the work of Marwat (2002a), Marwat et.al., (2002a), and Sarir (1998), who reported that minimum grasses weeds $\mathrm{m}^{-2}$ were recorded in narrow row spacing. While minimum number of grasses weeds in broad-spectrum 
herbicide treated plots were due to the presence of isoproturon in broad-spectrum herbicide, which controlled grasses weeds. Minimum grassy weeds $\mathrm{m}^{-2}$ in the interaction of broad spectrum herbicide and $20 \mathrm{~cm}$ row spacing might be due to its best combination as less space was available for grassy weeds development and application of broad spectrum herbicide controlled grasses weeds. These findings are in agreement with Marwat et.al., (2002) and Marwat et.al., (2002a), who reported that interaction of broad spectrum herbicide and narrow row spacing suppressed weeds population more effectively.

\subsection{Broad leaved weed density $\left(\mathrm{m}^{-2}\right)$}

The effect of row spacing, herbicides and interaction of row spacing and herbicides on broad leaf weeds density $\mathrm{m}^{-2}$ were highly significant. Among row spacings, $20 \mathrm{~cm}$ row spacing had minimum broad leaf weeds $\left(26 \mathrm{~m}^{-2}\right)$ followed by $30 \mathrm{~cm}\left(31.33 \mathrm{~m}^{-2}\right)$ and $40 \mathrm{~cm}\left(35.33 \mathrm{~m}^{-2}\right)$. While minimum broad leaf weeds $\left(12 \mathrm{~m}^{-2}\right)$ were recorded in broad-spectrum herbicide treated plots followed by broad leaf herbicide $\left(19.33 \mathrm{~m}^{-2}\right)$ and weedy check $\left(61.33 \mathrm{~m}^{-2}\right)$, where no herbicide was used (Table 2). For row spacing $\mathrm{x}$ herbicides interaction, minimum $\left(10 \mathrm{~m}^{-2}\right)$ and maximum $\left(72 \mathrm{~m}^{-2}\right)$ broad leaf weeds $\mathrm{m}^{-2}$ were observed in row spacing $20 \mathrm{~cm}$ with broad-spectrum herbicide and row spacing $40 \mathrm{~cm}$ with control treatment, respectively (Table 2). Maximum number of broad-leaved weeds in treatments of wider row spacing might be due to more space available for weeds development, while narrow row spacing suppressed weeds growth. These results are in agreement with the work of Marwat et al. (2002), Marwat et. al., (2002a) and Khan et al. (2002), who concluded that with the closer row spacing $(18$ and $15 \mathrm{~cm})$, the weed growth rate was lower, and light interception, crop growth rate and grain yield were higher than with the wider row spacing. Among herbicides, minimum broad leaf weeds were recorded in broad-spectrum herbicide treated plots, which might be due to efficient control of broad leaf weeds. These findings were in agreement with the results of Marwat (2002a) and Marwat et.al., (2002a) who found that broad spectrum herbicide (Isoproturon + 2,4-D) controlled weeds population more effectively as compared to grasses weeds killer or broad leaf herbicide used alone. Minimum broad leaf weeds recorded in the interaction of $20 \mathrm{~cm}$ row spacing and broad-spectrum herbicides might also be due to less space available for weeds growth in narrow row spacing, and also application of broad-spectrum herbicide controlled broad leaf weeds. These results were also in agreement with the work of Marwat (2002a) and Marwat et.al., (2002a) who enunciated that with the closer row spacing $(15$ and $20 \mathrm{~cm}$ ), the weed growth rate was slower, and light interception, crop growth rate and grain yield were higher. The broad-spectrum herbicide (Isoproturon + 2,4-D) controlled weeds population more effectively as compared to grasses weeds killer or broad leaf herbicide used alone.

\subsection{Spikelets spike $e^{-1}$}

The effect of herbicides on spikelets spike ${ }^{-1}$ was significant, while that of row spacing and interaction of herbicides with row spacing was non-significant. The maximum spikelets spike ${ }^{-1}$ were observed in broad spectrum herbicide $(2,4-\mathrm{D}+$ isoproturon) treated plots followed by broad leaved herbicide and weedy check (Table 3). The highest spikelets spike ${ }^{-1}$ in broad spectrum herbicide treated plots might be due to control of both grasses and broad leaved weeds density and consequently wheat crop solely used plant nutrients and other resources, which might have increased spikelets spike ${ }^{-1}$. These findings are in agreement with the work of Marwat (2002) and Khan et al. (2001), who reported that maximum spikelets spike ${ }^{-1}$ were the result of application of broad spectrum herbicide (2,4-D+ isoproturon) and (Puma + Logran).

3.4 Grains spike ${ }^{-1}$

The effect of herbicides, row spacing and interaction of row spacing with herbicides were highly significant. The maximum grains spike ${ }^{-1}$ (55.07) were recorded in broad spectrum followed by broad leaved (53.50) herbicide, while minimum grains spike ${ }^{-1}$ (52.07) were recorded in the weedy check (Table 4). Among row spacings, the highest grains spike $^{-1}$ were found in $30 \mathrm{~cm}$ (54.73), followed by $20 \mathrm{~cm}$ (54.06), while minimum was recorded in $40 \mathrm{~cm}$ (51.83) row spacing. In row spacing $\mathrm{x}$ herbicides interaction, the highest grains spike ${ }^{-1}$ were recorded in $30 \mathrm{~cm}$ row space treated with broad-spectrum herbicide (56.70), while minimum grains were counted in $40 \mathrm{~cm}$ row spacing with weedy check plots (51.20) (Table 4). Maximum grains spike ${ }^{-1}$ in broad-spectrum herbicide treated plots might be due to the control of both grasses and broad leaved weeds and thus wheat crop might have used nutrients sufficiently, which could have ultimately increased number of grains spike ${ }^{-1}$. These findings are in agreement with the work of Marwat (2002), who found that maximum grains spike ${ }^{-1}$ were recorded in plots treated with broad spectrum herbicide. Maximum grains spike $^{-1}$ recorded in $30 \mathrm{~cm}$ row spacing might be due to suitable row space for higher grains spike ${ }^{-1}$. These findings are in accordance with the work of Marwat (2002), who reported that maximum grains spike ${ }^{-1}$ were found in row spacing 25 $\mathrm{cm}$ at Peshawar and row spacing $30 \mathrm{~cm}$ at Dera Ismail Khan.

\subsection{Grain yield $\left(t h a^{-1}\right)$}

The effect of row spacing, herbicides and row spacing $\mathrm{x}$ herbicide on grain yield $\left(\mathrm{t} \mathrm{ha} \mathrm{h}^{-1}\right)$ was highly significant. The highest grain yield was observed in $20 \mathrm{~cm}\left(4.80 \mathrm{t} \mathrm{ha}^{-1}\right)$ row spacing, followed by $30 \mathrm{~cm}\left(4.43 \mathrm{t} \mathrm{ha}^{-1}\right)$ and $40 \mathrm{~cm}(4.23 \mathrm{t}$ $\mathrm{ha}^{-1}$ ) respectively (Table 5). Among herbicide treatments, maximum grain yield $\left(4.83 \mathrm{t} \mathrm{ha}^{-1}\right)$ was recorded in broad-spectrum herbicide, which was significantly different from broad leaf $\left(4.45 \mathrm{tha}^{-1}\right)$ and control treatment plots 
(Table 5). The effect of row spacing $\mathrm{x}$ herbicides interaction on grain yield was also significant. The highest grain yield $\left(5.35 \mathrm{t} \mathrm{ha}^{-1}\right)$ was recorded in $20 \mathrm{~cm}$ row spacing treated with broad spectrum herbicide, while minimum grain yield $\left(4.00 \mathrm{t} \mathrm{ha}^{-1}\right)$ was recorded in $40 \mathrm{~cm}$ row spacing with control treatment (Table 5). The maximum grain yield observed in $20 \mathrm{~cm}$ row spacing, broad spectrum herbicide and interaction of $20 \mathrm{~cm}$ row spacing $\mathrm{x}$ broad spectrum herbicides was due to the fact that productive tillers $\mathrm{m}^{-2}$ were more in row spacing $20 \mathrm{~cm}$ and broad spectrum herbicide as compared to other two row spacing $(30 \mathrm{~cm}$ and $40 \mathrm{~cm})$ and broad leaved and weedy check treatments. These results are in agreement with the work of Marwat (2002a), Marwat et al (2002) and Malik et al (1996) who reported that grain yield and straw yield were highest at 18 and $15 \mathrm{~cm}$ row spacing and decreased at wider row spacing. In case of broad spectrum herbicide, both narrow and broad leaf weeds were controlled by application of narrow + broad leaf herbicides and ultimately increased grain yield. These findings are in agreement with the work of Marwat (2002a), Marwat et al (2002) and Azad et al (1997) who reported that post-emergence application of isoproturon + 2,4-D was found to be the best treatment combination in reducing dry matter of weeds and producing the greatest straw and grain yield compared to control treatment.

\subsection{Harvest Index (\%)}

The effect of row spacing, herbicides and row spacing $\mathrm{x}$ herbicides interaction on harvest index was significant. Among row spacing the highest harvest index (32.66) was recorded in $20 \mathrm{~cm}$ row spacing, followed by $30 \mathrm{~cm}$ row spacing (31.09) and lowest harvest index was observed in row spacing $40 \mathrm{~cm}$ (Table 6). Maximum harvest index was found in broad spectrum (33.49), followed by broad leaf (31.29), while minimum was recorded in control treatment (Table 6). From the interaction of row spacing $\mathrm{x}$ herbicides, the highest harvest index was observed in row space $20 \mathrm{~cm} \times$ broad spectrum herbicide (35.91), followed by row spacing $30 \mathrm{~cm}$ x broad spectrum herbicide (32.78), while lowest harvest index (29.10) was computed for row spacing $40 \mathrm{~cm}$ with control (Table 6). The highest harvest index recorded in row spacing $20 \mathrm{~cm}$, herbicide broad spectrum and interaction of row spacing $20 \mathrm{~cm}$ x broad spectrum herbicide might be due to maximum productive tillers $\mathrm{m}^{-2}$ found in row spacing $20 \mathrm{~cm}$ and broad spectrum herbicide, which controlled both narrow and broad leaf weeds and the up take of maximum soil nutrients by wheat crop increased grain yield and thus harvest index was increased. These findings are in agreement with the work of Marwat (2002), who found that the higher harvest index was recorded in narrow row spacing and application of broad-spectrum herbicide.

\subsection{Net income (Rs. $\mathrm{ha}^{-1}$ )}

The effect of herbicides, row spacing and herbicides $\mathrm{x}$ row spacing was significant. Table 7 revealed that maximum net income (Rs.29748 ha ${ }^{-1}$ ) was found in broad-spectrum herbicide, followed by broad leaf (Rs. $26450 \mathrm{ha}^{-1}$ ), while minimum was in control treatment (Rs.24828 ha $\mathrm{ha}^{-1}$ ). Among row spacing, maximum net income (Rs.29655 has ${ }^{-1}$ ) was recorded in $20 \mathrm{~cm}$ row spacing, followed by $30 \mathrm{~cm}\left(\right.$ Rs. $26538 \mathrm{ha}^{-1}$ ) and $40 \mathrm{~cm}$ (Rs. $24838.33 \mathrm{ha}^{-1}$ ), respectively (Table 7). Comparing the interaction, highest net income (Rs. $34140 \mathrm{ha}^{-1}$ ) was found in row spacing $20 \mathrm{~cm}$ treated with broad spectrum herbicide, followed by $30 \mathrm{~cm}$ row spacing (Rs. $28615 \mathrm{ha}^{-1}$ ) plots sprayed with broad spectrum herbicide, while minimum net income was found in $40 \mathrm{~cm}$ row spacing and with weedy check treatment (Table 7). The maximum net income recorded in broad spectrum herbicide might be due to the fact that broad spectrum herbicide containing both narrow and broad leaved herbicides, controlled both kinds of weeds effectively and grain and straw yield of wheat was increased which ultimately increased the net income. These findings are in agreement with the work of Marwat et al (2002a) and Kotru et al., (1999) who reported that post-emergence application of isoproturon + 2,4-D gave the highest benefit cost ratio of 2.57 and 1.38 and net profit of Rs.35350 and Rs.712.5 $\mathrm{ha}^{-1}$, respectively. The highest net income recorded in row spacing $20 \mathrm{~cm}$ was due to maximum productive tillers $\mathrm{m}^{-2}$, which increased both grain and straw yield of wheat and effectively increased net income. These findings are in agreement with the work of Marwat et al (2002a) and Pattanaik et al., (1996) who reported that closer unidirectional sowing + integrated weed management resulted in the highest net returns (Rs. 35433 and Rs. $5753 \mathrm{ha}^{-1}$, respectively) and the highest net return for each Rupee invested (Rs. 2.57 and 1.72, respectively). The narrow rowed sowing was superior in field and more economical.

\section{References}

Anonymous. (2004). Agriculture Statistics of Iran, Government of Iran, Ministry of Food, Agriculture and Cooperatives. Food and Agriculture Division (Planning Unit), Tehran.

Anonymous. (2005). Agriculture Statistics of Center of Iran, Agriculture Extension Department, Government of Tehran State, Tehran.

Arnon, I. (1972). Crop Production in Dry Regions. Leonard Hill Book, London.

Ashrafi, Z.Y, H. R.Mashadi, S. Sadeghi and Robert E. Blackshaw. (2009). Study Effects of Planting Methods and Tank Mixed Herbiciedes on Weeds Controlling and Wheat Yield. Journal of agriculture science 1 (1): 101-111.

Azad, B.S., H. Singh, S.C. Gupta and H. Singh. (1997). Effect of plant density, doses of herbicides and time of nitrogen application on weed suppression and its efficiency in wheat (Triticum aestivum). Indian Env. and Ecol, 15 (3): 665-668. 
Burns, W. (1944). The technological possibilities of increasing crop yields. J. Amer. Soc. Agron., 85:132- 154

Dwyer, L.M., M. Tollenaar and D.W. Stewart. (1991). Changes in plant density dependence of leaf photosynthesis of maize (Zea mays L.) hybrids, 1959 to 1988. Can. J. Plant Sci., 71:1-11.

Gomez, K.A. and A.A. Gomez. (1984). Statistical Procedure for Agric. Res. $2^{\text {nd }}$ Ed., Willey and Sons, New York, USA. Hassan, G. and K.B. Marwat. (2001). Integrated Weed Management in agricultural crops. Proc. National Workshop on technologies for Sustainable Agriculture, Sep. 24-26, 2001, NIAB, Faisalabad, Pakistan, pp. 27-34 (ISBN 969-8038-09-4).

Iqbal, S. (1994). Screening of different herbicides for controlling weeds in wheat crop. M.Sc. (Hons) Thesis, Faculty of Agriculture, Gomal University, Dera Ismail Khan.

Khan, I., Z. Muhammad, G. Hassan and K.B. Marwat. (2001). Efficacy of different herbicides for controlling weeds in wheat Crop.1. Response of agronomic and morphological traits in wheat variety Ghaznavi-98. Scientific Khyber 14(1):51-57.

Khan, I., G. Hassan and K.B. Marwat. (2002). Efficacy of different herbicides for controlling weeds in wheat crop-II. Weed dynamics and herbicides. Pak. J. Weed Sci. Res., 8(1-2):41-47.

Kotru, R., B.S. Azad and H. Singh. (1999). Chemical control of weeds in wheat (Triticum aestivum L.) in India. Env. and Ecol., 17(3): 646-649.

Malik, M.A., M. Haroon-ur-Rasheed and A. Razzaq. (1996). Row spacing study on two wheat varieties under rainfed conditions. Sarhad J. Agric. 12(1): 31-36.

Marwat, M.I. (2002). Effect of weed management practices and row spacing on weed control in different wheat cultivars in NWFP. Pakistan. Ph.D. Dissert., Department of Agronomy, Faculty of Agriculture, Gomal University, Dera Ismail Khan, pp.69-84.

Marwat, M.I. (2002a). Effect of weed management practices on different traits of wheat. OnLine J. Biol. Sci., 2(11):719-721.

Marwat M.I., H.K. Ahmad, K.B. Marwat and G. Hassan. (2002). Integrated weed management in wheat. I. Weed density, dry weed biomass, absolute growth rate and grain yield. Pak. J. Weed Sci. Res., 8 (1-2): 81-93.

Marwat, M.I., H.K. Ahmad, H.H. Khan and A. Khan. (2002a). Effect of weed management practices on economic traits in wheat. OnLine J. Biol. Sci., 2(11):722-724.

Pattanaik, A., B.D. Behera and S.C. Panda. 1996. Effect of seeding geometry and weed management on weed growth, nutrient uptake and economics of wheat cultivation in Orissa. Env. and Ecol., 14(3): 631-635.

Rahnavard, A., Ashrafi, Z.Y., Alizade, H.M. and Sadeghi, S. (2009). Studies on the effect of fertilizer application and crop rotation on the weed infestated fields in Iran. Journal of Agricultural Technology 5(1): 41-50.

Tollenaar, M. and A. Aguilera. (1992). Ear and kernel formation in maize hybrids representing three decades of yield improvement. Crop Sci., 32:432-438.

Young, F.J.L., A.G. Ogg, Jr., R.I. Papendick, D.C. Thill and J.R. Alldredge. (1994). Tillage and weed management affects winter wheat yield in an integrated pest management system. Agron. J., 86:147-154.

Table 1. Effect of row spacing, herbicides and their interaction on grasses weeds density $\mathrm{m}^{-2}$ in wheat

\begin{tabular}{|l|c|c|c|c|}
\hline \multirow{2}{*}{ Herbicides } & \multicolumn{3}{|c|}{ Row spacing $(\mathrm{cm})$} & \multirow{2}{*}{ Herbicide means } \\
\cline { 2 - 5 } & 20 & 30 & 40 & $12 \mathrm{a}$ \\
\hline Broad Spectrum & $8 \mathrm{a} *$ & $12 \mathrm{~b}$ & $16 \mathrm{c}$ & $35 \mathrm{~b}$ \\
\hline Broad Leaf & $27 \mathrm{~d}$ & $35 \mathrm{f}$ & $43 \mathrm{~g}$ & $38 \mathrm{~b}$ \\
\hline Weedy check & $31 \mathrm{c}$ & $40 \mathrm{~g}$ & $43 \mathrm{~g}$ & \\
\hline Row spacing mean & $22 \mathrm{a}$ & $29 \mathrm{~b}$ & $34 \mathrm{c}$ & \\
\hline LSD value for row spaces, herbicide and row space $x$ herbicide $=3.57$ \\
\hline
\end{tabular}

* Means not sharing a common letter in the respective category differ significantly at $1 \%$ level of probability. 
Table 2. Effect of row spacing, herbicides and their interaction on broad leaved weeds density $\mathrm{m}^{-2}$ in wheat

\begin{tabular}{|l|c|c|c|c|}
\hline \multirow{2}{*}{ Herbicides } & \multicolumn{3}{|c|}{ Row spacing $(\mathrm{cm})$} & Herbicide means \\
\cline { 2 - 5 } & 20 & 30 & 40 & $12 \mathrm{a}$ \\
\hline Broad Spectrum & $10 \mathrm{a}^{*}$ & $12 \mathrm{a}$ & $14 \mathrm{ab}$ & $19.33 \mathrm{~b}$ \\
\hline Broad Leaf & $18 \mathrm{bc}$ & $20 \mathrm{c}$ & $20 \mathrm{c}$ & $61.33 \mathrm{c}$ \\
\hline Weedy check & $50 \mathrm{~d}$ & $62 \mathrm{e}$ & $72 \mathrm{f}$ & \\
\hline Row spacing mean & $26 \mathrm{a}$ & $31.33 \mathrm{~b}$ & $35.33 \mathrm{~b}$ & \\
\hline LSD value for row spaces, herbicide and row space $\mathrm{x}$ herbicide $=4.26$ \\
\hline
\end{tabular}

*Means not sharing a common letter in the respective category differ significantly at $1 \%$ level of probability.

Table 3. Effect of row spacing, herbicides and their interaction on spikelets spike ${ }^{-1}$ in wheat

\begin{tabular}{|l|c|c|c|c|}
\hline \multirow{2}{*}{ Herbicides } & \multicolumn{3}{|c|}{ Row space $(\mathrm{cm})$} & \multirow{2}{*}{$\begin{array}{c}\text { Herbicide } \\
\text { means }\end{array}$} \\
\cline { 2 - 4 } & 20 & 30 & 40 & $19.40 \mathrm{a}$ \\
\hline Broad Spectrum & $19.60^{*}$ & 19.20 & 18.40 & $18.60 \mathrm{~b}$ \\
\hline Broad Leaf & 18.60 & 18.70 & 17.90 & $18.07 \mathrm{~b}$ \\
\hline Weedy check & 18.20 & 18.10 & 18.60 & \\
\hline Row spacing mean & $18.80 \mathrm{NS} *$ & 18.66 & \multicolumn{2}{|c|}{} \\
\hline \multicolumn{2}{|l|}{ LSD value for row spaces, herbicides and row space x herbicide $=0.59$} \\
\hline
\end{tabular}

* NS: Non-significant. * Means not sharing a common letter in the respective category differ significantly at $1 \%$ level of probability.

Table 4. Effect of row spacing, herbicides and their interaction on number of grains spike ${ }^{-1}$ in wheat

\begin{tabular}{|l|c|c|c|c|}
\hline \multirow{2}{*}{} & \multicolumn{3}{|c|}{ Row spacing (cm) } & \multirow{2}{*}{ Herbicide means } \\
\cline { 2 - 4 } Herbicides & 20 & 30 & 40 & $55.07 \mathrm{a}$ \\
\hline Broad Spectrum & $56.10 \mathrm{a}$ & $56.70 \mathrm{a}$ & $52.40 \mathrm{~d}$ & $53.50 \mathrm{bc}$ \\
\hline Broad Leaf & $54.10 \mathrm{bc}$ & $54.50 \mathrm{~b}$ & $51.90 \mathrm{de}$ & $52.07 \mathrm{c}$ \\
\hline Weedy check & $52.00 \mathrm{~d}$ & $53.00 \mathrm{~cd}$ & $51.20 \mathrm{e}$ & \\
\hline Row spacing mean & $54.06 \mathrm{~b}$ & $54.73 \mathrm{a}$ & $51.83 \mathrm{c}$ & \\
\hline \multicolumn{2}{|c|}{ LSD value for row spaces, herbicide and row space x herbicide $=1.47$} \\
\hline
\end{tabular}

* Means not sharing a common letter in the respective category differ significantly at $1 \%$ level of probability.

Table 5. Effect of row spacing, herbicides and their interaction on grain yield $\left(\mathrm{t} \mathrm{ha}^{-1}\right)$ in wheat

\begin{tabular}{|l|c|c|c|c|}
\hline \multirow{2}{*}{ Herbicides } & \multicolumn{3}{|c|}{ Row space $(\mathrm{cm})$} & \multirow{2}{*}{ Herbicide means } \\
\cline { 2 - 5 } & 20 & 30 & 40 & $4.83 \mathrm{a}$ \\
\hline Broad Spectrum & $5.35 \mathrm{a}$ & $4.70 \mathrm{~b}$ & $4.45 \mathrm{c}$ & $4.45 \mathrm{~b}$ \\
\hline Broad Leaf & $4.70 \mathrm{~b}$ & $4.40 \mathrm{c}$ & $4.25 \mathrm{~cd}$ & $4.18 \mathrm{c}$ \\
\hline Weedy check & $4.35 \mathrm{c}$ & $4.20 \mathrm{de}$ & $4.00 \mathrm{e}$ & $4.23 \mathrm{c}$ \\
\hline Row spacing mean & $4.80 \mathrm{a}$ & $4.43 \mathrm{bc}$ & 0.209 & \\
\hline LSD value for row spaces, herbicide and herbicide x row space $=4$ & \\
\hline
\end{tabular}

* Means not sharing a common letter in the respective category differ significantly at $1 \%$ level of probability. 
Table 6. Effect of row spacing, herbicides and their interaction on harvest index (\%) in wheat

\begin{tabular}{|l|c|c|c|c|}
\hline \multirow{2}{*}{ Herbicides } & \multicolumn{3}{|c|}{ Row space $(\mathrm{cm})$} & \multirow{2}{*}{ Herbicide means } \\
\cline { 2 - 5 } & 20 & 30 & 40 & $33.49 \mathrm{a}$ \\
\hline Broad Spectrum & $35.91 \mathrm{a}$ & $32.78 \mathrm{~b}$ & $31.79 \mathrm{bc}$ & $31.29 \mathrm{bc}$ \\
\hline Broad Leaf & $31.97 \mathrm{~b}$ & $31.10 \mathrm{c}$ & $30.80 \mathrm{~cd}$ & $29.83 \mathrm{c}$ \\
\hline Weedy check & $30.10 \mathrm{~d}$ & $29.41 \mathrm{de}$ & $29.10 \mathrm{e}$ & $30.56 \mathrm{~b}$ \\
\hline Row spacing mean & $32.66 \mathrm{a}$ & $31.09 \mathrm{ab}$ & \multicolumn{2}{|c|}{} \\
\hline LSD value for row spaces, herbicide and row space x herbicide $=1.66$ & \\
\hline
\end{tabular}

* Means not sharing a common letter in the respective category differ significantly at 1\% level of probability.

Table 7. Effect of row spacing, herbicides and their interaction on net income (Rs. ha $\left.{ }^{-1}\right)$ in wheat

\begin{tabular}{|l|c|c|c|c|}
\hline \multirow{2}{*}{} & \multicolumn{3}{|c|}{ Row space (cm) } & \multirow{2}{*}{} \\
\cline { 2 - 4 } & 20 & 30 & 40 & Herbicide means \\
\hline Herbicides & 34140 & 28615 & 26490 & 29748 \\
\hline Broad Spectrum & 28580 & 26030 & 24755 & 26450 \\
\hline Weedy check & 26245 & 24970 & 23270 & 24828 \\
\hline Row spacing mean & 29655 & 26538 & 24838 & \\
\hline
\end{tabular}

* Means not sharing a common letter in the respective category differ significantly at $1 \%$ level of probability. 